This is the peer reviewed version of the following article: Angew. Chem. Int. Ed. 2016, 55,3260, which has been published in final form at: https://doi.org/10.1002/anie.201509853

DOI: $10.1002 /$ anie.201509853

Authorprofile

\title{
Stephan Schulz
}

\section{Date of July 12, 1966}

birth :

Position: Professor of Inorganic Chemistry, University of Duisburg-Essen

E-mail: stephan.schulzeuni-due.de

Homepage: https://wWw.uni-

due.de/ak<?_>schulz/index<?_>en.php

Education: 1992 Undergraduate degree, University of Göttingen

1994 PhD supervised by Herbert W. Roesky, University of Göttingen

1994--1996 Postdoctoral position with

Richard F. Jordan, University of Iowa 2001 Habilitation

$\begin{array}{ll}\text { Awards: } & 1994 \text { Research Fellowship (Deutsche } \\ & \text { Forschungsgemeinschaft); } 1996 \text { Liebig } \\ & \text { Fellowship (Fonds der Chemischen } \\ & \text { Industrie); } 1999 \text { Fellowship for } \\ & \text { Habilitation (Deutsche } \\ & \text { Forschungsgemeinschaft) } \\ & \text { Structure and reactivity of (low-valent) } \\ \text { Current } & \text { organometallic compounds and their } \\ \text { interests: } & \text { application in materials synthesis } \\ \text { Hobbies: } & \text { Jogging, watching soccer, spending time } \\ & \text { with friends and family }\end{array}$


S. Schulz

The most important thing I learned from my students is ... to be prepared for everything.

The principal aspect of my personality is ... to tell things as they are.

The natural talent I would like to be gifted with... is not to tell things as they are.

If I could be a piece of lab equipment, I would be ... an NMR tube since I like to spin around.

My motto is ... "Maach et joot, ävver nit zo off" (a saying from the Rhineland meaning "do it well, but not too often", i.e. quality over quantity) .

I am waiting for the day when someone will realize ... that scientific discoveries not necessarily follow three-year research programs.

Last time I went to the pub ... my friends and I solved almost every problem in the world - unfortunately we couldn't remember the next day. If I could be anyone for a day, I would be ... food taster for Keith Richards (but only for one day).<?>Any particular reason?<?>No particular reason

I admire ... people with a consistent life plan who always know exactly what comes next.

I advise my students to ... explore their own way in life, and to be careful with advice given by people like me.

The secret of being a successful scientist is ... something I am still looking for.

My favorite structure is ... that of chlorine azide - a beautiful beast. 


\section{My 5 top papers:}

$<$ lit1>"Van der Waals epitaxial MoCVD-growth of $\left(\mathrm{Bi}_{\mathrm{x}} \mathrm{Sb}_{1<\mathrm{M}->\mathrm{x}}\right)_{2} \mathrm{Te}_{3} \quad(0<\mathrm{x}<1)$ films": G. Bendt, J. Sonntag, A. Lorke, W. Assenmacher, U. Hagemann, S. Schulz, Semicond. Sci. Technol. 2015, 30, 085021. (Chemistry plays an essential role in materials science.)

<lit2>"Temperature-Dependent Electron Shuffle in Molecular Group 13/15 Intermetallic Complexes": C. Ganesamoorthy, D. Bläser, C. Wölper, S. Schulz, Angew. Chem. Int. Ed. 2014, 53, 11587; Angew. Chem. 2014, 126, 11771. (Understanding electronic interactions is the most important thing in chemistry.)

<lit3>"A Comparison of the Solid-State Structures of Halogen Azides $\mathrm{XN}_{3}$ $(X=C l, B r, I) ":$ B. Lyhs, D. Bläser, C. Wölper, S. Schulz, G. Jansen, Angew. Chem. Int. Ed. 2012, 51, 12859; Angew. Chem.

2012, 124, 13031. (The compounds show remarkable different intermolecular interactions in the solid state.)

<lit4>"Synthesis of Hexagonal $\mathrm{Sb}_{2} \mathrm{Te}_{3}$ Nanoplates by Thermal Decomposition of the Single-Source Precursor (Et $\left.{ }_{2} \mathrm{Sb}\right)_{2} \mathrm{Te} ": \mathrm{S}$. Schulz, S. Heimann, J. Friedrich, M. Engenhorst, G. Schierning, W. Assenmacher, Chem. Mater. 2012, 24, 2228. (Illustrates the great potential of singlesource precursors in materials synthesis.)

<lit5>"Structural Characterization of a Base-Stabilized [Zn2]2+ Cation":

S. Schulz, D. Schuchmann, I. Krossing, D. Himmel, D. Bläser, R. Boese, Angew. Chem. Int. Ed. 2009, 48, 5748; Angew. Chem. 2009, 121, 5859. (The $\left[\mathrm{Zn}_{2}\right]^{2+}$ dication became accessible only when using the principle of base stabilization.)

The author presented on this page has recently published his 10th article in Angewandte Chemie in the last 10 years:

<lit6>"A Gallium-Substituted Distibene and an Antimony-Analogue Bicyclo[1.1.0]butane: Synthesis and Solid-State Structures": L. Tuscher, C. Ganesamoorthy, D. Bläser, C. Wölper, S. Schulz, Angew. Chem. Int. Ed. 2015, 54, 10657; Angew. Chem. 2015, 127, 10803. 


\section{DuEPublico}

This text is made available via DuEPublico, the institutional repository of the University of Duisburg-Essen. This version may eventually differ from another version distributed by a commercial publisher.

DOI: $\quad 10.1002 /$ anie. 201509853

URN: urn:nbn:de:hbz:464-20201203-165129-9

This is the peer reviewed version of the following article: Angew. Chem. Int. Ed. 2016, 55, 3260, which has been published in final form at: https://doi.org/10.1002/anie.201509853

All rights reserved. 